\title{
Mustafa Kemal Paşa'nın Sovyet Rus ve Azerbaycan Büyükelçileri ile 5. Süvari Kolordusunu Teftişi ve Ilgın'ı Ziyaretleri
}

\author{
DOI: $10.26466 /$ opus.342187
}

\section{Cemal Güven $^{*}$}

*Prof. Dr., Necmettin Erbakan Üniversitesi, Ahmet Keleşoğlu Eğitim Fakültesi, Konya/Türkiye E-Posta: cemalguven@gmail.com ORCID: $\underline{0000-0001-5649-1273}$

Öz

Türkiye Büyük Millet Meclisi Reisi ve Başkomutan Mustafa Kemal Paşa, Sovyet Rus ve Azerbaycan Büyükelçileri ve askerî ataşeleri ile birlikte, Büyük Taarruz öncesinde 28 Mart - 4 Nisan 1922 tarihleri arasında Sivrihisar, Çay, Akşehir, Ilgın ve Konya'yı kapsayan cephe ve cephe gerisi ziyareti ve teftişi yapmışlardır. Bu kapsamda 1 Nisan 1922'de Mustafa Kemal Paşa misafirleriyle birlikte Ilgıı'da Fahrettin (Altay) Paşa komutasındaki 5. Süvari Kolordusunu teftiş etmiş ve akabinde ilçe merkezini ziyaret etmişlerdir. Bu çalışmada olayın tanıkları ve dönemin basınından yararlanılarak konunun detayları ortaya konmuştur.

Anahtar Kelimeler: Millî mücadele, Mustafa Kemal, Fahrettin Altay, süvari, Ilgın. 


\title{
Inspection of the 5th Cavalry Corps of Mustafa Ke- mal Pasha with the Soviet Russian and Azerbaijani Embassies and their Ilgin Visits
}

DOI: $10.26466 /$ opus.342187

\begin{abstract}
Mustafa Kemal Pasha, the president of the Turkish Grand National Assembly and the Commanderin-Chief, visited and inspected the front line and hinterland including Sivrihisar, Çay, Akşehir, Ilgin and Konya between 28 March and 4 April 1922 before the Great Offensive together with the Soviet Russian and Azerbaijani Embassies and with their military attaches. In this context, Mustafa Kemal Pasha inspected the 5th Cavalry Corps under the command of Fahrettin (Altay) Pasha in Ilgin together with his guests on April 1, 1922 and then visited the county town. In this study, details of the subject were suggested by using the witnesses of the event and the press of the time.
\end{abstract}

Key Words : National struggle, Mustafa Kemal, Fahrettin Altay, cavalry, Ilgin. 


\section{Giriş}

Mustafa Kemal Paşa, Sovyet Rus Büyükelçisi Aralov ve Azerbaycan Büyükelçisi Abilov ve askerî ataşeleri ile birlikte 28 Mart - 4 Nisan 1922 tarihleri arasında Sivrihisar, Çay, Akşehir, Ilgın ve Konya'yı kapsayan cephe ve cephe gerisi ziyareti ve teftişi yapmışlardı. Mustafa Kemal Paşa'nın bizzat davetleriyle gerçekleşen bu ziyaret ve teftişler, Sovyet büyükelçilerine Türk askerî birliklerinin ve halkın genel durumunun ve moralinin yerinde gösterilmesi bakımından önemlidir. Zira TBMM Hükümetine ve askerî birliklerine güvenlerinin daha sağlam temellere oturması ve neticede Sovyet askerî ve mâlî yardımının daha ziyade alınması bakımından sonuç getirici nitelikte olmuştur (Güven, 2006, ss.58-60).

Batı Cephesi Karargâhının Akşehir'de olması, aynı zamanda Türk ordu birliklerinin bu merkez ve çevresinde konuşlanması durumunu da beraberinde getirmektedir. Bu kapsamda Türk ordusunun önemli bir unsurunu teşkil eden Fahrettin (Altay) Paşa komutasındaki 5. Süvari Kolordusu Ilgın'da konuşlanmıştır. 1., 2. ve 14. Süvari Tümenlerinden oluşan bu Kolordu yukarıda bahsedilen cephe ve cephe gerisi ziyaret ve teftişi kapsamında 1 Nisan 1922'de TBMM Reisi ve Başkomutan Mustafa Kemal Paşa tarafından misafirleriyle birlikte teftiş edilmiş ve akabinde ilçe merkezi ziyaret edilmiştir.

\section{Mustafa Kemal Paşa ve Misafirlerinin Ilgın'ı Ziyaretleri}

Ziyaretin bir gün öncesinden Ilgın'da karşılama hazırlıkları kapsamında yoğun bir faaliyet başlamıştı. Mustafa Kemal Paşa'nın Ilgın'a gelecekleri haberinin duyulması halkta büyük heyecana sebep olmuştu (Babalık, 4 Nisan 1922, nr. 859, s.1).

1 Nisan 1922 Cumartesi sabahı erkenden resmî binalar ve dükkânlar bayraklarla donatılmış, karşılama için koşuşan halk ve insan kitleleriyle Ilgın tarihî bir gün yaşamaya başlamıştı. II. İnönü Muharebesi zaferinin (30 Mart) yıldönümünün hemen akabine denk gelmesi heyecanı ve şevki artırıyordu. Oraya buraya koşuşan atılır arasında alaturka saat ikiye doğru öğrenciler ve memurlar, çocuk, kadın ve erkeklerden ibaret muazzam bir kitle karşılama mahalline doğru ilerliyordu. Kaplıca (llıca) Köprüsü'nün iki tarafında evvelce hazırlanan programa uygun şekilde yer 
alınmış ve herkes gözlerini kaplıcanın üzerindeki tepeye yönelterek heyecanla beklemeye koyulmuştu (Babalık, 4 Nisan 1922, nr. 859, s.1) ${ }^{1}$.

Nihayet uzun bir müddet bekleyişin ardından alaturka saat beş buçuk altıya doğru yokuştan otomobillerin gelişi görülmeye başlanmış ve halk, Mustafa Kemal Paşa'yı otomobilinde görebilmek arzusuyla oradan oraya koşuşturmaya başlamıştı (Babalık, 4 Nisan 1922, nr. 859, s.1; Hâkimiyet-i Milliye, 16 Nisan 1922, nr.483, s.1).

Teftişe hazır olmak üzere dizilmiş askerî kıtaat tarafından yapılan resmigeçite müteakip tümenlerin manevrası teftiş edilmiş (Babalık, 4 Nisan 1922, nr. 859, s.1; Hâkimiyet-i Milliye, 16 Nisan 1922, nr.483, s.1) ve konuşmalar yapılmıştır. Bir sonraki bölümde bu konuya değinilecektir. Teftişe müteakip halkın karşılama mahalline yönelinmiştir.

Batı Cephesi Karargâhı Akşehir'den hareket edip Ilgın'a ulaşan Mustafa Kemal Paşa'nın beraberinde, İsmet Paşa, Rus Büyükelçisi Aralov, Ataşemiliteri Zvanayov (Zvonaryev), Elçilik Katibi İsmailov, tercümanı Feyzi, Azerbaycan Büyükelçisi Abilov ve Ataşemiliteri Askerov, Başkatibi İsmailov, Başyaver Salih, Refakat Subayı Binbaşı Mahmut, Yüzbaşı Hilmi, Yaver Muzaffer, Kâtip Memduh Beyler bulunmaktaydı. Mustafa Kemal Paşa, beraberindekiler ile birlikte karşılama mahallindeki köprünün diğer tarafında bekleyenlere doğru ilerleyerek erkân ve memurlara bol bol iltifat etmiş bu arada karşılama güzergâhına koşan minik öğrenciler önünde durarak, "Nasılsınız küçük hanımlar, efendiler?" diyerek gönüllerini almış, müteakiben halkın hatırlarını sormuştur. Daha sonra otomobillere binmişler ve doğruca ikametlerine tahsis olunan daireye teşrifle bir müddet dinlenmişlerdir (Babalık, 4 Nisan 1922, nr. 859, s.1; Hâkimiyet-i Milliye, 16 Nisan 1922, nr.483, s.1).

Mustafa Kemal Paşa ve misafirleri şerefine aynı mahsus dairede Ilgın Belediyesi tarafından kırk kişilik bir öğle ziyafeti verilmiştir (Babalık, 4 Nisan 1922, nr. 859, s.1)². Mustafa Kemal Paşa daha sonra Kaymakam İbnülrefik Emin Bey vasıtasıyla hükümet erkânı ve memurlarıyla belde eşrafını kabul ederek, hâl ve hatırlarını sorup gönüllerini almıştır (Babalık, 4 Nisan 1922, nr. 859, s.1; Hâkimiyet-i Milliye, 16 Nisan 1922, nr.483, s.1).

\footnotetext{
${ }^{1}$ Fahrettin Paşa hatıratında, 1 Mart günü geldiklerini yazmaktadır. Baskı hatası vardır. Bkz. (Altay, 1970, s.316).

2 Menüde şunlar vardır: Terbiyeli çorba, kuzu kızartması, taze bakla, börek, tatlı, pilav ve meyve. Bkz. (Babalık, 4 Nisan 1922, nr. 859, s.1).
} 
Mustafa Kemal Paşa ve misafirleri alaturka saat ona doğru coşkulu bir uğurlama merasimiyle (Babalık, 4 Nisan 1922, nr. 859, s.1; Hâkimiyet-i Milliye, 16 Nisan 1922, nr.483, s.1) Ilgın'dan trenle Konya'ya gitmek üzere ayrılmışlardır. Aralov hatıratında, İsmet Paşa ile candan vedalaştıklarını, Paşa'nın cepheden fazla uzaklaşmamak geleneğine sadık kalarak, bütün ricalarına rağmen kendileriyle birlikte Konya'ya gelmeye razı olmadığını belirtmektedir (Aralov, 1985, s. 103) ${ }^{3}$.

\section{Beşinci Süvari Kolordusunun Teftişi (1 Nisan 1922)}

5. Süvari Kolordusunun komutanı Fahrettin Paşa, Mustafa Kemal yaklaşınca, yalın kılınç yanına koşmuş ve tekmîl haberini vermişti. Burada Mustafa Kemal Paşa ile beraberindekilere binek atları verilmişti (Aralov, 1985, s. 102).

Daha önceden verilen bir emirle 1., 2. ve 14. süvari tümenlerinden oluşan 5. Süvari Kolordusu kaplıca meydanına ${ }^{4}$ toplatılmıştı. Başkomutan Mustafa Kemal Paşa ile Cephe Komutanı İsmet Paşa taraflarından teftiş edildi ve küçük bir manevra ile bir geçit resmî yaptırıldı. Beraberlerinde Sovyet Rusya büyükelçisi S. İ. Aralov, Azerbaycan büyükelçisi İbrahim Abilov ve her iki elçiliğin askerî ataşelerinin de bulunduğu bu manevrada atlıların süratle açılıp yayılması oldukça heybetli olmuştu. Birkaç bin atlının dörtnala yaptığı resmigeçit bütün herkesi büyük bir heyecana boğmuş ve memnuniyetler dile getirilmişti (Altay, 1970, s.316; Altay, 1949, s.38) ${ }^{5}$.

\footnotetext{
${ }^{3}$ Fahrettin Paşa hatıratında yanlış bir bilgi olarak Akşehir'deki piyadeleri teftişe gittikleri bilgisini vermektedir. Bkz. (Altay, 1970, s.316).

Yukarıda belirtildiği üzere Konya'ya gitmişlerdir. Ismet Paşa ise Akşehir'deki karargâhına dönmüştür. Bkz. (Önder, 1998, s.318).

${ }^{4}$ Manevranın yapıldığı bölgenin adı "Koca Çayır"dır. Bkz. (Ali Boran vd., 2011, s.51).

5 “... Bu geçit resminde Atatürk'ün önünden geçen her subay ve er onun takdir ve ümitle parlayan gök gözlerinden aldığı enerji ve iftihar duyguları istikbal zaferimizin müeyyidesi olmuştur. O geçit resminin fotoğraflarında Atatürk'ün boynunda asılı görülen ve Azerbaycanlılar tarafından hediye edilmiş olan gümüş kaplı eski bir kılıcı daha sonra bana vermek lûtfunda bulunmuşlardır. Ben bu kılıcı yine kendisi tarafından verilmiş soyadım gibi bütün istikbâl Altaylarına yadigâr bırakmakla iftihar duymaktayım." Bkz. (Altay, 1949, s.38).

"Geçit resminde Gazi Mustafa Kemal'in belinde asılı gümüş işlemeli antika kılıcı kendisine Azarbeycanlılar hediye etmişlerdi. Daha sonra Atatürk de bu kılıcı Cumhuriyetin ilk yıllarında bana hediye etmek lütfunda bulunmuştu. Şimdi evimde her zaman gözlerimin önünde duran kılıca baktıkça süvari birliklerinin geçişi sırasında Mustafa Kemal'in gözlerinde parlayan ümit ışılarını görür gibi oluyorum." Bkz. (Altay, 1970, s.317).
} 
Resmigeçitten ve küçük bir manevradan sonra, Mustafa Kemal Paşa alayları toplayarak şu konuşmayı yapmıştır: "Askerler... Savaş artık bizim yüzümüze gülmeğe başladı. Ingilizlerin boğazlanmak üzere gönderdiğ Yunanliları yeniyoruz. İngiliz emperyalistleri bizi yok etmek istiyorlar, ama bunu başaramayacaklardır. Türk halkı ve Türk ordusu, kendi bağımsızlığı için savaşa girişmiş bulunuyor ve düşmanlarını, kendi kutsal topraklarından atacaktır. Sovyetler Birliği'nin elçisi de burada, bizimle birlikte bulunuyor" (Aralov, 1985, s. 102).

$\mathrm{Bu}$ sözlerinin ardından, Sovyet Büyükelçisi Aralov'dan da bir konuşma yapmasını rica etmiştir. Bunun üzerine Aralov at üzerinde ${ }^{6}$ yaptığı konuşmasında; "Yiğit ve soylu erler" diyerek sözlerine başlamış ve Kızıl ordu askerlerinin selâmını getirdiğini söylemiştir. Bu arada Mustafa Kemal Paşa, Fahrettin Paşa'ya bir şeyler söylemiş, $\mathrm{O}$ da elini sallaması üzerine süvariler, Kızıl ordu şerefine "çok yaşa" diye bağırmışlardı. Aralov sözlerini şöyle sürdürmüştü: “... Rus işçi ve köylüsü iktidarı ellerine alarak yeni bir devlet kurmaktadırlar. Sevgili dostlarm, sizin de yeni Türkiye'nin düşmanların yenmenizi, aziz yurdunuzu kurtarmanızı, İzmir ve İstanbul şehirlerini geri almanızı dilerim. Kızlordu, soylu davranışınıla sizin de orduya ve bağ̆ımsız Türkiye'ye şeref kazandıracă̆ınıza inanmaktadır". Bu konuşma yeniden "Yaşa" sözleriyle kesilmiş, Fahrettin Paşa, General Budyonny'e selâmlarının iletilmesini rica etmişti (Aralov, 1985, s. 103)7 .

İki gün önce Afyon Çay'da piyadelerin teftişine katılan Aralov, yaptığ kıyası hatıratında şu cümlelerle vermektedir: "Süvarilerin görünüşü piyadelerden çok daha canlıydı. Kılık kıyafetleri yalın tekdüzeydi. Hemen hepsinin ayağında çizme vardı. Atlar iyi, ama ayrı ayrı donlardaydı." Ayrıca Sovyet heyetinin 5. Süvari Kolordusunun toplam gücü hakkında bilgilendirildiği anlaşılmaktadır. Nitekim Aralov Kolordunun mevcudunun 6000 kılıç

\footnotetext{
${ }^{6}$ Aralov hatıratında ayrıca şunları kaydetmektedir: "Eğerin üstünde, binicilik kurallarına göre doğru oturup oturmadığımı bilmiyorum. Ama, atım rahat duruyordu. Bütün gözler bana dönmüştü. Yanımda Abilov vardı." Bkz. (Aralov, 1985, s.103).

${ }^{7}$ Aralov hatıratında, Fahrettin Paşa'yı, işinin ehli ve cesur bir süvari olduğunu ve Türklerin onu Rus Generali Budyonny'e benzettiklerini kaydetmektedir. Bkz. (Aralov, 1985, s. 103).

Aralov hatıratında, Fahrettin Paşa'nın adını yanlış olarak "Fahri" olarak yazmaktadır. Bkz. (Aralov, 1985, s. 102).

Kazak asıllı olan Semyon Mikhailovich Budyonny, Kızıl Orduda etkin rol alan ünlü süvari komutanıdır.
} 
olduğunu, topçu ve makineli tüfekçiler dâhil 8000 kadar at olduğunu belirtmektedir. Bu rakamlar Fahrettin Altay'ın verdiği bilgilere yakındır (Aralov, 1985, s. 102) . $^{8}$

Fahrettin Paşa hatıratında, Mustafa Kemal Paşa'nın elçileri beraberinde getirmelerine önce bir anlam veremediğini, bunun gerekçesini daha sonra öğrendiğini şu cümlelerle anlatmaktadır: "Ruslar her ne kadar o sıralarda dostumuz idiyseler de cephe kuvvetlerini onlara göstermekteki maksadı anlayamamıştık. Çok sonra öğrenmiştik ki, Ruslar bize müşterek savaş teklif etmişler ve bu maksatla Zonguldak, Ereğli'ye asker çıkarmak ve Kocaeli'nde beraber savaşmak istemişler. Bizim kuvvetlerimizin de düşmanları İstanbul'dan çıkarmaya kâfi gelmeyeceğini ileri sürmüşler. Bundaki gizli maksadı Mustafa Kemal anlamaz, olur muydu?(...) Derhal: 'Benim kuvvetim İzmir'i de İstanbul'u da kurtarmak için kafidir' demiş ve bunu fiilen göstermek için onlarm elçileri ve ataşeleriyle bu seyahati tertiplemiştir." Fahrettin Paşa, Rusların müşterek savaş teklifini, o zaman genel karargâhta kurmay olarak bulunan Korgeneral Baki Vandemir'den duyduğunu nakletmektedir (Altay, 1970, s.316-317).

Mustafa Kemal Paşa teftişten sonra not defterine şu bilgi ve düşüncelerini kaydetmiştir (Türkmen, 2004, s.214, 220)'

“1 Nisan 1338 (1922), Yeni araçların, yeni olağan kanunların kullanılıp uygulanmasından dolayı süvarinin savaşa katılış şeklinde değişiklikler olmuştur. Fakat bu değişim, süvarinin yüklendiğgi görevin özünü değiştirmez. Yeteri derecede hızlı ve manevraya büyük bir kıvraklık kazandırmak süvarilerin en önemli görevlerindendir."

"Süvari savaştan evvel bir savunma aracl, savaştan sonra ise bir hücum aracıdır. Ateş, süvari savaşının en önemli ve en belirgin özelliklerindendir. Geçmiş zamanlarda sonuçlar kesin ve çetin mevzii savaşlarından alınıyordu. Bugün kuvvet ateştedir. Süvari kolordusunu Ilgın'da denetledik. Akşam Konya'ya ulaştık. Saat 7.30'da coşkun bir şekilde karşılandık."

\footnotetext{
${ }^{8}$ Fahrettin Paşa Kolordusunun mevcudu hakkında şu bilgileri vermektedir: Beşinci Süvari Kolordusu, 1., 2. ve 14. Süvari Tümenlerinden oluşmaktadır. Toplam: 550 Subay, $9900 \mathrm{Er}, 9480$ Hayvan, 6450 Tüfek, 48 Makinalı Tüfek, 4800 Kılıç, 620 Bomba ve 16 Dağ Topuna sahiptir. Bu güce Seyyar Hastane, Hayvan Hastanesi ve Nakliye Kolları dâhil Değildir. Bkz. (Altay, 1949, s.39).

${ }^{9}$ Belirtilen atıftaki makalede 15 Nisan 1922'de gerçekleştirilen Büyük Süvari Manevrası Teftişi konusu ele alınmaktadır. Ancak makalenin bazı kısımlarında 1 Nisan 1922 tarihli teftiş ve ziyarette yaşanan hadiseler ile karıştıııldığı görülmektedir.
} 
Gerçekten de Büyük Taarruz ile on dört gün gibi kısa bir sürede, Türk süvari birliklerinin büyük katkısıyla, Yunan işgal kuvvetleri Anadolu'dan tard edilmiştir.

\section{Sonuç}

Askerin ve halkın morale ihtiyaçları olduğu, durumun yerinde tespitinin önemli olduğu bir dönemde Başkomutan ve misafirleri tarafından Ilgın'da konuşlanan ve taarruz hazırlıklarını yürüten 5. Süvari Kolordusunun teftişi ve ilçe merkezinin ziyaret edilmesi Millî Mücadele tarihi açısından önem taşımaktadır.

Fahrettin Altay Paşa eserlerinde teftişte yaşanan hadiseleri gururla nakletmektedir. Dosta güven düşmana korku salan süvari birliklerimizin Büyük Taarruz'da kati neticeyi almada mühim rolü olmuştur. Bu süreçte Yunan piyade ve süvari birlikleri Türk süvari birliklerinin karşısına çıkmaya hiçbir zaman cesaret edememiştir.

Büyük Taarruz arifesindeki en önemli sorun ordunun mâlî ve askerî ihtiyaçlarının karşılanması hususudur. Millî Mücadele döneminde Sovyet Rusya' dan alınan mâlî ve askerî yardımların büyük değeri olmuştur. Türk ordusunun taarruz hazırlıklarını sürdürdüğ̈̈ ve yeterli destek sağlanırsa kati neticenin alınabileceği hususu Sovyet büyükelçilerine de yerlerinde gösterilmesi önemlidir. 28 Mart - 4 Nisan 1922 tarihleri arası yapılan cephe ve cephe gerisi ziyaret ve teftişleri kapsamında 1 Nisan'da Ilgın'da 5 . Süvari Kolordusunun teftişi ve ilçe merkezinin ziyaret edilmesinin, belirtilen hususa katkı sağladığı söylenebilir. 


\section{EKLER}

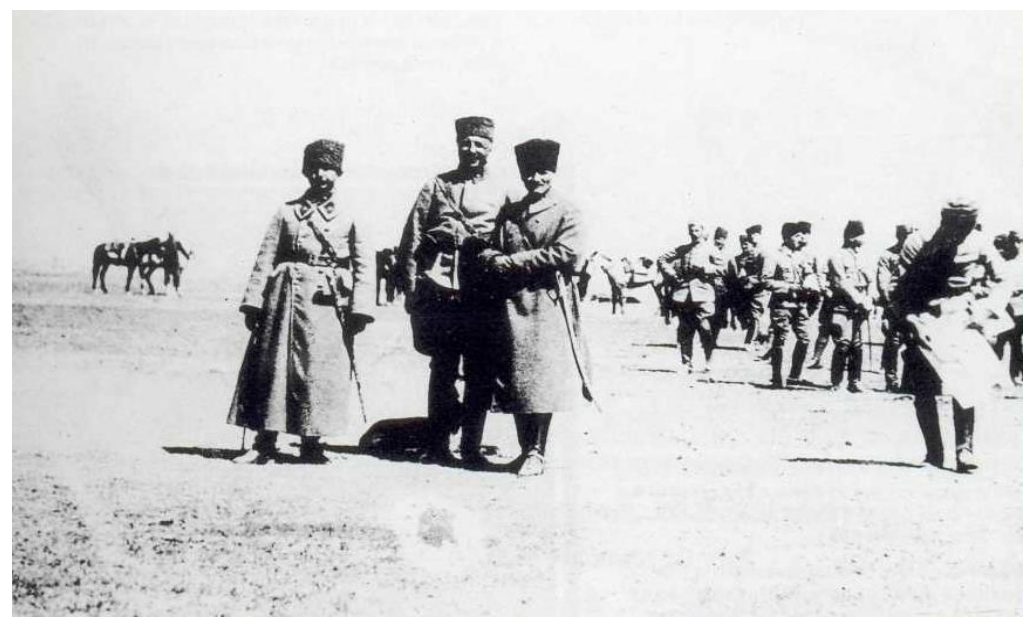

Ilgin Manevrasinda (1 Nisan 1922)

Batı Cephesi Komutanı İsmet Paşa ve 5. Süvari Kolordusu Komutanı Fahrettin Altay Paşa'yla

(Ülger, 1996, s.186)

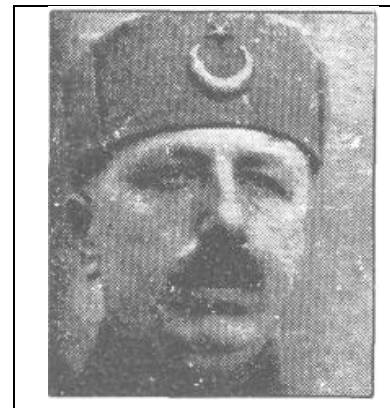

5. Süvari Kolordusu Komutanı

\section{Fahrettin (Altay) Paşa}

(TBMM Albümü, 1994, s. 39)

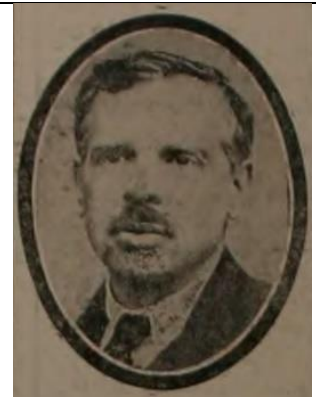

Sovyet Rus Büyükelçisi Semiyon İvanoviç Aralov

(Vakit, 26 Mayıs 1922, nr.1602, s.1)

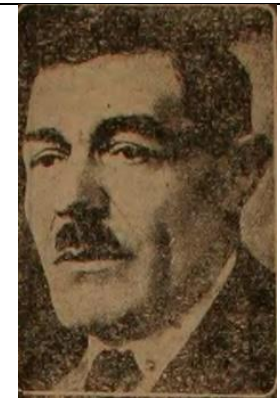

Azerbaycan SSC Büyükelçisi İbrahim Abilov (Anadolu'da Yeni Gün, 29 Haziran 1922, nr.529-906, s.1) 


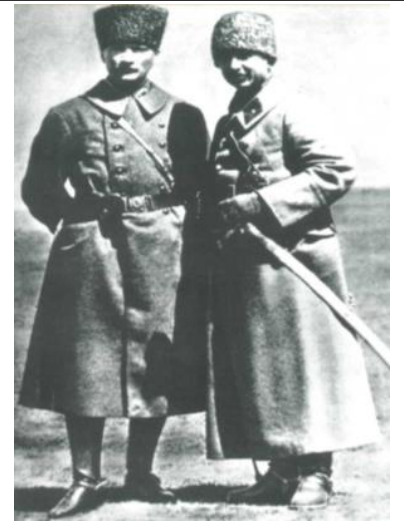

Ilgin Manevrasinda (1 Nisan 1922)

Batı Cephesi Komutanı İsmet Paşa'yla (Özel, 2001, s. 34)

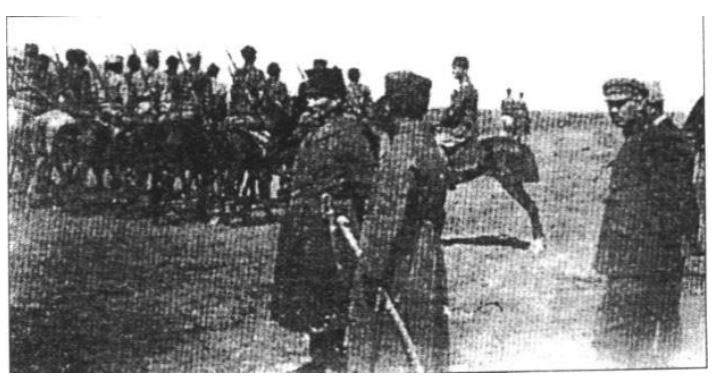

Ilgin Manevrasinda (1 Nisan 1922)

Arkalarında Sovyet Rusya Büyükelçisi S. İ. Aralov ve Azerbaycan Büyükelçisi İ. Abilov (Aslan, 2002, s.131)

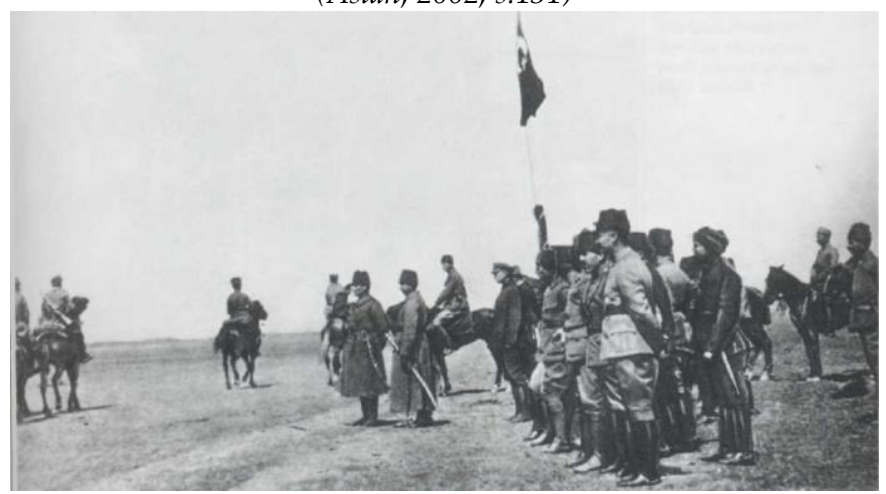

Ilgin Manevrasinda (1 Nisan 1922) 


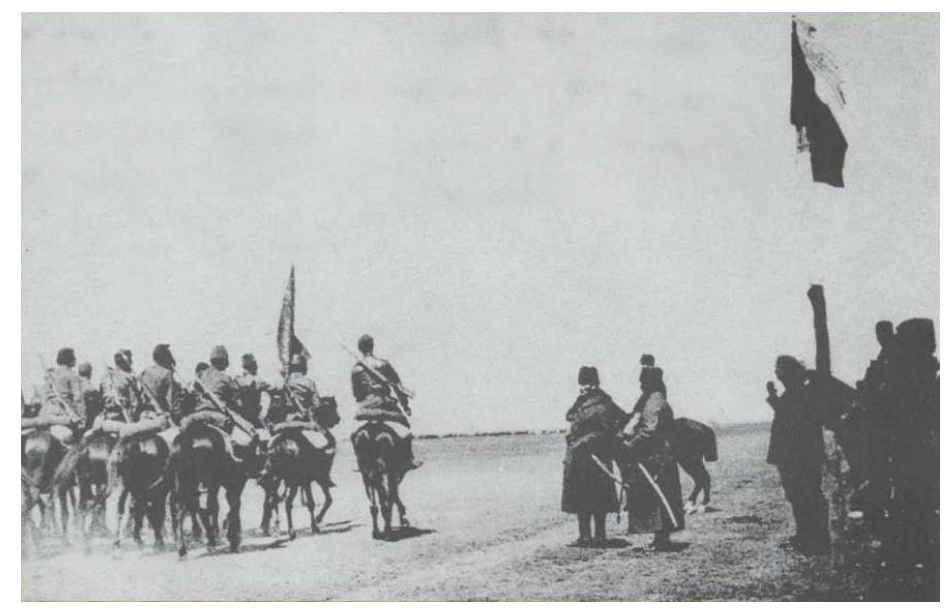

Ilgin Manevrasinda (1 Nisan 1922)

(Ülger, 1996, s.187)

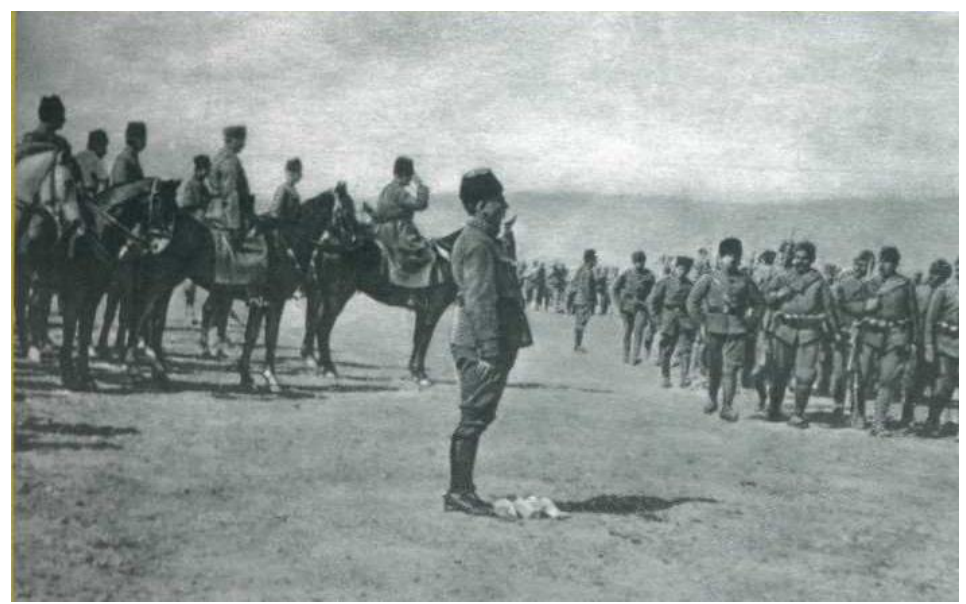

Ilgin Manevrasinda (1 Nisan 1922)

(Özel, 2001, s.34) 


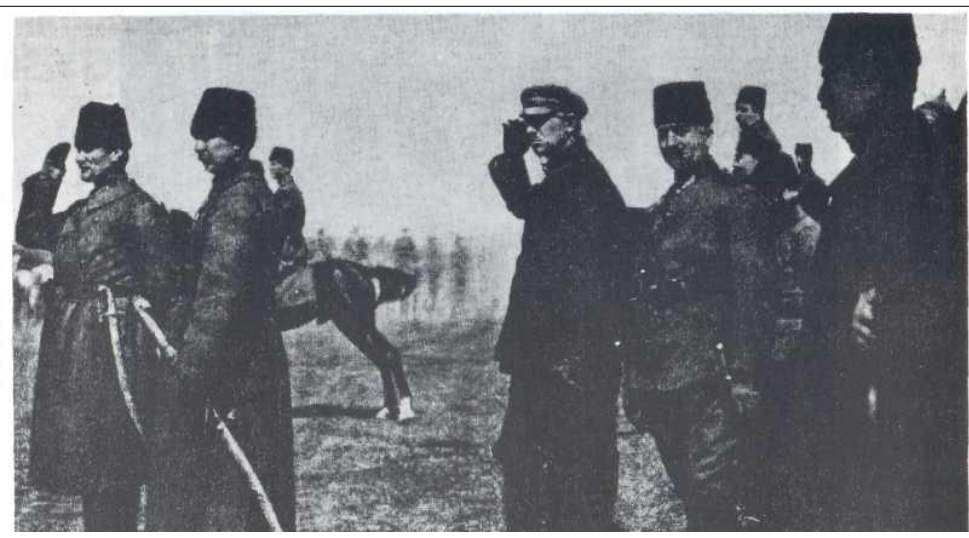

Ilgin Manevrasinda (1 Nisan 1922)

Başkomutan Gazi Mustafa Kemal Paşa ve Garp Cephesi Komutan İsmet (İnönü) Paşa'nın arkasında Türk Süvarilerini selamlayan Rus Büyükelçisi S. I. Aralov'dur. Yanında

1. Süvari Tümeni Komutanı Albay Mürsel (Bakû) ve Kurmay Binbaşı Kâzım (İnanç) görülüyor.

(Çarpan, 1996, s. 91)

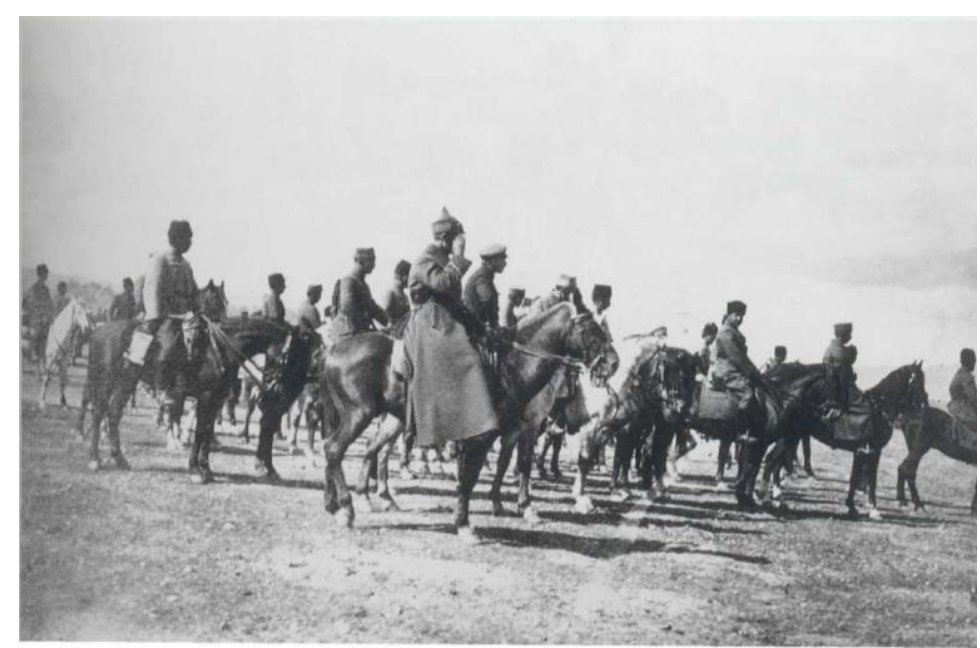

Ilgin Manevrasinda (1 Nisan 1922)

Mustafa Kemal Paşa, Azerbaycan Büyükelçisi İ. Abilov, Sovyet Rusya Büyükelçisi S. I. Aralov ve Sovyet Rusya Ateşesi Zvonaryev ile. 


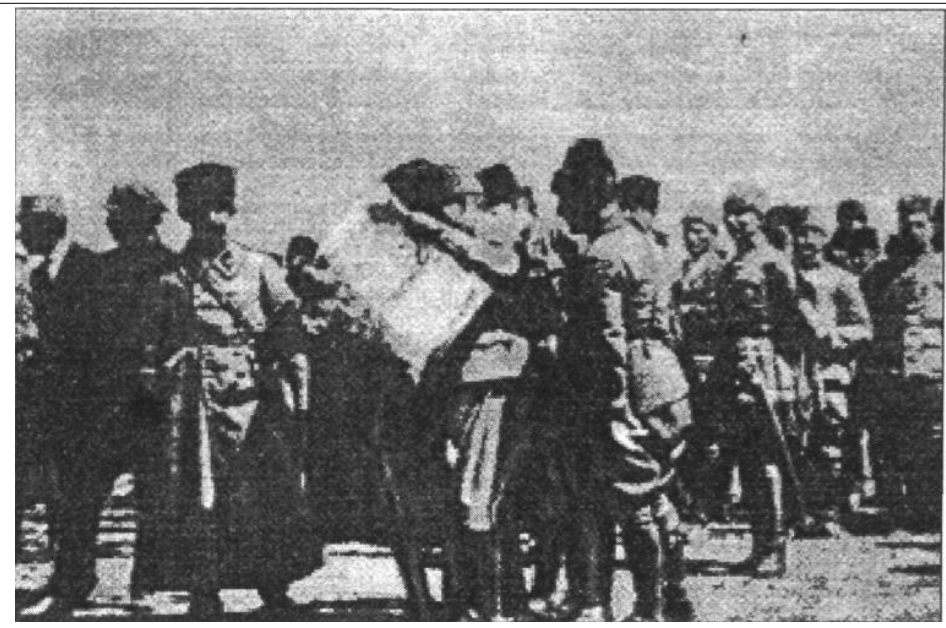

Ilgin Manevrasinda (1 Nisan 1922)

İsmet Paşa'nın arkasinda Sovyet Rusya Büyükelçisi S. I. Aralov ve Azerbaycan

Büyükelçisi İ. Abilov.

(Aslan, 2002, s.134)

\section{KAYNAKÇA}

Anadolu'da Yeni Gün, 29 Haziran 1922, nr.529-906, s.1.

Babalık, 4 Nisan 1922, nr. 859, s.1.

Hâkimiyet-i Milliye, 16 Nisan 1922, nr.483, s.1.

Vakit, 26 Mayıs 1922, nr.1602, s.1.

Altay, F. (1970). Görüp geçirdiklerim 10 yıl savaş ve sonrası 1912-1922. İstanbul: İnsel Kitabevi.

Altay, F. (1949). İstiklâl harbimizde suvari kolordusu. İstanbul: İnsel Kitabevi.

Aralov, S. İ (1985). Bir Sovyet diplomatı'nın Türkiye anıları. Ankara: Birey Toplum Yayınları.

Aslan, Y. (2002). Mustafa Kemal - M. Frunze görüşmeleri Türk Sovyet ilişkilerinde zirve. İstanbul: Kaynak Yayınları.

Boran, A. vd. (Editör) (2011). Bütün yönleriyle Ilgın, Ilgın: Ardıçlıform Matbaacilik.

Boran, A. (2013). Ilgın kültür envanteri, Konya: Ilgın Belediyesi Yayınları.

Çarpan, N. (1996). Atatürk albümü, Ankara: Yeni Mesnevi Yayım ve Turizm Endüstrisi A.Ş.

Güven, C. (Nisan-2006). Mustafa Kemal Paşanın Büyük Taarruz öncesinde Sovyet Rus ve Azerbaycan elçileri ile cephe ve cephe gerisi 
gezisi (Sivrihisar - Çay- Akşehir- Ilgın - Konya). Yeni İpek Yolu Konya Ticaret Odası Dergisi, (218), 58-60.

Önder, M. ( 1998). Atatürk'ün yurt gezileri. Ankara: Türkiye İş Bankası Kültür Yayınları.

Özel, M. ( 2001). Atatürk. Ankara: Kültür Bakanlığı Yayınları.

Türkiye Büyük Millet Meclisi Albümü. (1994). Ankara: TBMM Genel Sekreterliği Yayınları.

Türkmen, Z. (Mart 2004). Mustafa Kemal Paşanın Büyük Taarruz öncesinde süvari kolordusunu denetlemesi ve Ilgin manevrasinda süvari kolordusu. Atatürk Araştırma Merkezi Dergisi, (XX, 58), 203230.

Ülger, S. E. (1996). Özgün belge ve fotoğraflarla Mustafa Kemal Atatürk. Ankara: TBMM Vakfı Yayınları.

\section{Kaynakça Bilgisi / Citation Information}

Güven, C. (2017). Mustafa Kemal Paşa'nın Sovyet Rus ve Azerbaycan büyükelçileri ile 5. süvari kolordusunu teftişi ve Ilgın'ı ziyaretleri. OPUS-Uluslararası Toplum Araştırmaları Dergisi, 7(13), 1017-1030. 